\title{
OS TRATADOS SOBRE TEATRO DE RAFAEL DIESTE
}

\author{
Por \\ ARTURO CASAS
}

Na primeira etapa do seu exilio bonaerense, cabe supoñer que alentado polos seus traballos de recomposición de Viaje y fin de don Frontán e Quebranto de doña Luparia con destino á triloxía Viaje, duelo y perdición (Buenos Aires, Atlántida, 1945), Rafael Dieste volve a escribir teoría teatral e dramática (como xa fixera en 1935 en «Revelación y rebelión del teatro» ${ }^{1}$ ), a cal, nalgunhas ocasións, non é allea a un pulo comparatista entre as artes plásticas e a escénica. En concreto, trátase de tres ensaios, de asunto e extensión diversos, dos que só o primeiro, «Tratado mínimo del arte de la escena», chegaría ao prelo (Correo Literario, 24, 1944 , p. 3), se ben nunha redacción abreviada en relación coa copia mecanográfica conservada no Arquivo Dieste. Os outros dous textos, con bastante probabilidade non pechados totalmente polo autor e en espera

\footnotetext{
${ }^{1}$ Non me ocuparei aquí desta importante peza, que estudiei noutro lugar (La teoría estética, teatral y literaria de Rafael Dieste, Santiago de Compostela, Universidade, 1997, pp. 324-347), por non considerala estrictamente un tratado sobre teatro senón un texto (meta-)dramático. A súa aportación fundamental é a de retomar criticamente as propostas do teórico inglés Edward Gordon Craig, ampliando os seus diálogos nun sentido que, insisto, é xa plenamente dramático, ou mesmo teatral (o autor, unha vez cumprido o exilio, mantivo o propósito de chegar a representalo). «Revelación y rebelión del teatro. Misterio polemístico en una jornada» apareceu por vez primeira na revista madrileña P.A.N., 7 (1935), pp. 153-163, dirixida por Xosé Otero Espasandín e auspiciada por Eduardo Dieste. Recóllese en Rafael Dieste, Teatro I, ed. de Manuel Aznar Soler, Madrid, Laia, 1981, pp. 59-94.
}

"CUADERNOS DE ESTUDIOS GALLEGOS", Tomo XLVI, Fascículo 111, Santiago 1999. 
dunha reconsideración que nunca tivo lugar, recibiron os títulos de «Notas un tanto descuidadas de Félix Muriel»e «El teatro en el Arte y el arte del teatro».

No seu conxunto pode considerarse que este corpo teórico ten unha notábel relevancia, que é en realidade dobre, pois, ademais das propostas de índole estética que incorporan, estes tratados poden lerse así mesmo como unha poética teatral persoalmente asumida polo dramaturgo e home de teatro Rafael Dieste. A tendencia común dos tres á concisión e a un xeito de expresividade pragado de imaxes e quebros aforísticos, extraordinariamente suxerente desde o punto de vista do estilo e os achados ofrecidos, pero tamén algo imprecisa no conceptual ${ }^{2}$, responde a una modulación moi típica da razón poética tan cara ao autor, presente xa con todos os condicionantes descritos no célebre «Limiar» teórico a Dos arquivos do trasno (1926).

No «Tratado mínimo del arte de la escena» poderían recoñecerse o compendio dunha semiótica teatral e ao tempo unha poética da representación e un esbozo de dramaturxia (no sentido postbrechtiano do termo). En moi sucinta e incluso paradóxica síntese -extracto dun texto previo, perdido durante a Guerra Civil e reconstruído na memoria, o Breviario de estética teatral escrito en Bélxica en 1935-quedan cifradas as conviccións e propostas máis substanciais de quen a estas alturas acumulaba unha dilatada experiencia escénica e dramática, sendo tanxibeis tamén as pegadas dunha aprendizaxe que o puxera en contacto cos máis importantes teóricos teatrais do século XX.

Comeza o tratado asentando o principio da presencia activa nun granado parágrafo que non pasou á versión impresa, pero que agora, de modo excepcional ${ }^{3}$, convén rescatar aínda que sexa só polo que adianta:

\footnotetext{
${ }^{2}$ Véxase sobre isto Carlos Gurméndez, «El pensamiento de Rafael Dieste», Documentos A, 1 (1991), p. 72, onde partindo dunha consideración de Pedro Salinas, segundo a cal o pensamento español máis que discursivo tería tendido sempre a ser poético e aforístico, se conclúe que no caso de Dieste a obra ensaística acada unha intuición poética esencial, polo que o estudioso propón que se leve a cabo sobre ela unha lectura en canto «creación poética de la imaginación especulativa».

${ }^{3}$ En adiante, por interpretar que nel se representa a final vontade autorial, limitareime ao texto de Correo Literario, dividido en catro pequenos capítulos. Só tras rematar a súa lectura crítica retornarei brevemente ao orixinal. Sobre o principio da presencia activa precisará o autor conceptos no terceiro dos tratados mencionados.
}

"CUADERNOS DE ESTUDIOS GALLEGOS", Tomo XLVI, Fascículo 111, Santiago 1999. 
«Toda superficie que se sitúa frente a la mirada, o que la mirada sitúa frente a sí como presencia activa, crea por su virtud, o por nuestra manera de mirarla, un espacio mágico, aunque no se representa en ella el espacio real y aunque la ley de su unidad sea fantástica, decorativa e irreal. Una escultura lo crea en torno a sí, y también una peña solitaria. Un cuerpo arquitectónico lo anuncia, visto desde afuera, en su interior; y así conquista el ámbito exterior y lo transfigura». (Arquivo Dieste, p. 1).

Polo tanto, para Dieste, que aquí se limita a recuperar o sentido etimolóxico do que era o theatron para os gregos, o espectáculo está implícito xa na mera división do espacio en dous ámbitos, con tal de que un deles se configure para a expectación do outro. Entende o teórico que nisto non hai todavía diferencia ningunha en relación coa pintura, posto que o teatro comparte con esta arte un corolario da mesma lei espectacular da presencia activa, polo cal nin a superficie pictórica nin a escena representan a realidade que teñen fronte a si, senón que o que fan é tras-figurala, para finalmente restablecérennos ou confirmárennos o noso espacio. Tampouco se abren ángulos entre pintura e teatro en canto a unha segunda lei, agora de carácter formal, que viría a asegurar que a única correspondencia esixíbel á pintura e ao espectáculo é a das súas partes coa totalidade do creado (por isto mesmo advertirá Dieste contra as alusións caóticas, contra o ambiente que se insubordina e acaba dando pistas falsas ao espectador).

Sentadas tales bases, o tratadista analiza o vínculo entre drama e representación desde a perspectiva do dramaturgo, desde o acto creativo xa. Dieste móstrase convencido da existencia dun tránsito, pertencente aínda á imaxinación do autor, no cal a intuición dramática faise teatral, de modo que chegan a coparticiparse mutuamente «las virtudes espectaculares del drama y su valor de signo dramático». Así, todo drama ben pensado incorpora unha estructura teatral, polo que se non é parasitado resultará representábel. Orabén, por defecto ou por exceso -case sempre por isto último, sinala-, e xa na imaxinación autorial, o drama pode nacer condicionado e lastrado, orientándose ao fracaso escénico. Isto ocorrería de maneira especial cando os denominados «accidentes pintorescos» se enredan entre si, rebelándose contra a necesaria subordinación ao todo demandada desde un principio. E avisa explicitamente o tratadista contra unha 
das trampas que poden rebaixar o drama en dubidoso beneficio do efecto visual sobre o escenario: a beleza e harmonía espectaculares non son o fin último da representación, e nin sequera garanten nada alén do pasmo que acaso poida paralizar a un público determinado; indicación que de seu disolve calquera interpretación do texto como máis ou menos continuísta do rumbo aberto polo espectáculo global de raíz wagneriana e aínda da liña que poida representar o Totaltheater de Gropius e Piscator, en xeral asumido polo Bauhaus. É a outro factor ao que debe subordinarse calquera montaxe, incluíndo neste termo á mesma harmonía (tan só un medio): o máis puro designio teatral é -afirma Dieste-facer ao espectador testemuña dunha acción dramática:

«Con sobriedad o riqueza de accidentes, lo esencial es que todos atestigüen, por su significación, ritmo y virtud, que son signos de una total presencia dándose a conocer, no meros ornamentos, utensilios, masas inertes o alardes de ficción.

Todo lo que aparece en escena debe asistir al acto dramático; de lo contrario no debe aparecer. En la realidad hay muchas cosas y accidentes que están, pero no asisten... En el teatro aun la ausencia o sordera de las cosas debe ser un modo de asistir. Todo ha de participar según su ritmo y cualidad no sólo en la acción, sino en el acto de conocimiento dramático».

En función destas consideracións introduce unha crítica ao teatro usual, no que habitualmente -xulga- «nada asiste al drama», de modo que todo acaba por estorbar, desde a xestualidade ao movemento, desde a voz á disposición cromática. Convén insistir en que a reflexión diesteana segue a ter sempre como referente ao espectador. A recepción do fenómeno teatral é o que permite establecer criterios valorativos sobre a pertinencia e axuste da diversidade de signos teatrais; e isto é así por canto o inicial punto de partida establecía xa, como un axioma, que hai espectáculo porque hai un lugar de expectación. Segundo a sensibilidade de Dieste, como participante no público do tempo que somete a xuízo crítico, só a sublimación dalgúns signos permitía aos espectadores habituais unha interpretación da súa carga informativa, «pero en realidad permanecemos ausentes y sin siquiera enterarnos de la presencia de nuestra ausencia, lo cual ya sería divinamente dramático y, en altísimo grado, teatral». 
O tratadista localiza unha posíbel solución a ese estado de cousas na recuperación da máscara, entroncando así cunha tradición que, cando menos en principio, non é aquela coa que confesaba sentirse máis identificado tras os seus estudios en Bélxica e Francia nos anos previos á guerra española, a cal non era outra que a representada por Stanislavski. Con todo, non convén perdermos de vista o motivo que está detrás desta aposta, parece que conxuntural, pola reteatralización estilizadora e a anulación da transmisión psicolóxica dun carácter sobre a base da súa expresión facial. A máscara é unha solución ao esgotamento creativo e técnico do teatro ao uso. Pero ademais disto Dieste sinala a súa virtude principal na súa capacidade nominal, no seu poder para nomear, que vén sendo como unha mostración sostida do espírito que contempla e intervén. E aquí si que xa deixa de existir paralelismo coa pintura.

Sen embargo, o noso escritor vai moito máis alá do que puidera pensarse en función desta introducción. Sen descartar a mera utilización da máscara por parte dos actores propón en realidade algo de maior alcance, facer máscara de toda a escena. Prevén antes de entrar en detalles contra o reduccionismo que é corrente na concepción funcional daquela; establece un vínculo entre a súa inmutabilidade e a capacidade reveladora da voz que a acompaña, a cal, ben usada, fai transparente a máscara nun certo sentido, «y es así como siendo rígida en su límite es libre en su profundidad $\mathrm{y}$ ante los ojos, [asistindo] toda entera, en esencial quietud, a su íntima pasión». Pois ben, o que en fin delinea este tratado mínimo -resumo e interpreto- é o desenvolvemento dunha estética global do par máscaravoz, no que o segundo pólo se identifica co que está suxeito a inflexión, a mudanza, e o primeiro co invariábel; pero de novo baixo o designio de que este traspareza correlativamente naquel. Isto significa que a cada unha das materializacións nas que se puidese mostrar o concepto máscara, constitutivas (por multiplicación) dun ciclo con varias fases, correspondería, en principio biunivocamente, unha concreción do concepto voz. E xusto neste punto é onde se concentra o paradoxo anunciado, porque «siendo difícil mover todo un ciclo de máscaras y acordarlas a un tiempo con las perspectivas de la voz esencial, habría que encomendar su representación al rostro del actor. Y esto es lo que el rostro del actor debe representar».

É dicir, que en último termo, e á marxe doutras consideracións que se poidan e deban extraer, Dieste vén dar ao punto que foi o seu cabalo de batalla desde a crítica teatral exercida en El Pueblo Gallego e, dez anos 
despois, na etapa en que dirixiu o grupo teatral «Nueva Escena» (promovido pola Alianza de Intelectuales Antifascistas tras estalar a Guerra Civil), unha vez asimiladas as ensinanzas de Craig. E ese punto é o actor, o seu traballo sometido a unha orde marco, a súa coordinación; en definitiva, a necesidade de levar a cabo unha investigación sobre o seu cometido. O paradóxico estriba en que se teña que chegar ao actor desde a máscara, pero esta é xustamente a gran novidade que aporta a que parece revelársenos como síntese diesteana. Por isto mesmo puntualicei antes que parecía abrirse, prima facie, unha distancia entre o defendido polo tratadista e o sistema promovido por Konstantin Stanislavski. Pero en realidade non é iso. Estamos máis ben perante un regreso a Stanislavski ao través de $\mathrm{Craig}^{4}$ e, mesmo, aínda que sobre este punto a conxectura non poida sosterse en probas, ao través da disciplina do teatro oriental. De modo que, contemplado desde outro punto de vista o traxecto, poderíase dicir que Dieste adianta algúns dos presupostos de Jerzy Grotowski no seu Teatro Laboratorio de Wroclaw, ou os posteriores de Peter Brook ou Eugenio Barba. E nese sentido esixe que o rostro do actor posúa a fluidez de mutación suficiente para dar conta da multiplicación da máscara en todo o seu ciclo, en toda a pluralidade semiótica ofrecida desde o escenario, de xeito tal que se poidan contemplar as mans e o corpo daquel actor «con el mismo espíritu que nos hizo adivinar el sentido de la máscara». Pero Dieste non se contenta con ese esforzo. Impórtalle o actor, pero non desatende ao personaxe nin o seu entorno, pois para el a escena toda debe converterse nunha máscara cambiante, en pura representación, en superficie do ser transparentando o seu destino.

Neste punto remata a versión impresa do traballo. Pero, segundo adiantaba, importa saber que a estas reflexións seguían outras na primeira redacción. Sequera sexa mediante unhas breves notas convén precisar a súa orientación, que non é outra que a do establecemento dos que son denominados testemuños paralelos de autor e actor, das súas afinidades. Comezan por una renovada chamada á orde de quietude que ambos deberían experimentar no seu oficio, unha disciplina para a suxeición de todo

\footnotetext{
${ }^{4} \mathrm{O}$ teórico inglés escribiu no seu tratado On the Art of the Theater (Londres, Heinemann, 1911), que cito pola edición facsimilar de Theatre Arts Books, Nova York, 1956, que a conclusión á que todo actor fidel a si mesmo debería chegar un día era «that the mask is the only right medium of portraying the expressions of the soul as shown through the expressions of the face» (p. 13).
} 
ímpeto que se manifeste -nunha ou outra esfera- como «turbio simulacro». E lémbrase aquí que a serenidade non é sinónimo de frialdade, senón que ante todo é equilibrio: «La experiencia más apasionada, sin la cual es difícil un gran poeta, debe distanciarse y presentar su faz al quieto amor que la ilumine; y sólo entonces es posible el acto creador y su justicia» (Arquivo Dieste, p. 7). Cre Dieste que o personaxe é estraño ao poeta dramático. Este podería facerse personaxe de si mesmo, pero unicamente se conseguise contemplarse de forma inesperada e con estrañeza perante algunha sorte de espello, porque en definitiva é en exceso grande a autovixiancia do ser. O personaxe é o vínculo de autor e actor, sendo o problema deste último non deixar de ser quen é, o cal, segundo o tratadista, sería unha desgracia, posto que eliminaría o albedrío do actor.

$\mathrm{Na}$ concepción diesteana a arte do actor consiste en lograr que «un ritmo signifique una acción», subordinando sempre esa acción ao propio destino e virtude do personaxe. $O$ actor ten que dar a coñecer o espírito do personaxe, e ten que facelo mediante todas as ferramentas das que dispón, que se reducen a el mesmo, de modo que toda a súa presencia sexa «máscara con voz de poesía dentro». Sen embargo, iso non é todo. Dieste concede a palabra ao actor na parte final do tratado para que este confirme o seguinte:

«...en realidad no represento sólo el personaje, sino el drama, como una nube oscura significa el conflicto y presagios de todo el cielo en que navega. Así, toda la poesía del drama es como un gran espacio, y en él soy libre y siento las formas de mi gravitación fuera de mí como significativas apariencias con su acento justo, como si fuesen versos». (p. 8).

O segundo dos ensaios de teoría teatral escritos polo noso autor nun momento non ben determinado do exilio, pero tal vez non demasiado distante da etapa na que preparaba a triloxía Viaje, duelo y perdición, é «Notas un tanto descuidadas de Félix Muriel» $»^{5}$. O seu asunto fundamental xira

\footnotetext{
${ }^{5}$ Inédito, como se dixo. A copia mecanográfica conservada no Arquivo Dieste comprende vinte folios numerados correlativamente. Non ten divisións internas claras, se ben na páxina 12 destaca entre brancos tipográficos a lenda «El sacrilegio de Pigmalión». Aparecen en varios momentos sinopses do acadado previamente (pp. 6, 11 e 15). Nalgunha das partes o texto manifesta claramente o seu carácter de documento de traballo en espera de desenvolvemento posterior. Un exemplo é o que se atopa na p. 7: «Otras observaciones: Por qué me resisto a escribir tragedia. Por qué no me inclino decididamente a la comedia. Esquilo, Shakespeare, Molière, Lope, Calderón, Ibsen».
} 
en torno á discusión sobre a comedia e a traxedia, as súas funcionalidades, formas e efectos ${ }^{6}$. Configúrase así unha especie de dobre filosofía do tráxico e o cómico abocada (só relativamente) á dramaturxia. Non oculta o autor en ningún momento, por outra parte, a súa vocación de investigar os camiños que puidesen supoñer para o drama unha superación da escisión polarizadora que a máscara do choro e da risa viñeron representando. No conxunto do tratado, aínda que non haxa alusións explícitas, é apreciábel a asimilación e intento de desenvolvemento, por unha parte, dalgunhas das teses fundamentais de Friedrich Schelling, expostas a partir do seu System des transzendentalen Idealismus (1800) pero presentes como intuicións nos Briefe über Dogmatismus und Kritizismus (1795), e por outra -xa non pendente do tráxico senón do cómico-, dunha serie aberta de indagacións sobre a risa e a comedia entre as que destacarían algúns textos de Henri Bergson, en especial Le Rire (1900).

A traxedia é presentada aquí no marco do sacrificial, tendo en consecuencia un alcance relixioso que o autor se adianta a precisar que non exclúe outros posibeis. Trátase dun sacrificionecesario -e non meramente conveniente, práctico ou instrumental- que liga o humano co divino, como vira xa Hegel. A gravidade da traxedia descansaría para Dieste, precisamente, no recoñecemento daquela necesidade. Ao pé desa acción litúrxica, e atendendo agora á súa recepción polo público, sinálase nestas «Notas» a existencia dunha segunda orde sacrificial, constituída por «la caridad en el dolor» (p. 2), a cal non debería confundirse coa simple compaixón procurada desde a exemplaridade da traxedia. O irremediábel da dor tráxica provoca a asunción por parte do espectador da súa semellanza con aquel que cae ou padece, de xeito tal que, en termos schopenhauerianos, se produce unha traslación da esfera da representación á da vontade.

Pero tras Grecia, onde o carácter sagrado da traxedia se impuxo a calquera outra proxección, o ámbito do profano gañaría para si ao tráxico. Dieste proponse por isto indagar cal foi historicamente a xustificación sustentadora da continuidade do xénero. E, como noutros casos, os seus

\footnotetext{
${ }^{6}$ En dous traballos anteriores, centrados respectivamente en A fiestra valdeira e Viaje y fin de don Frontán, tiven ocasión de amosar algunhas correspondencias entre a teoría perfilada no ensaio e a concreción textual vixente naquelas pezas. Trátase de Rafael Dieste e a súa obra literaria en galego, Vigo, Galaxia, 1994, pp. 247-257, e «Traxedia e farsa en Don Frontán», Revista Galega de Teatro, 11 (1995), pp. 39-40.
} 
razoamentos vólvense agora cara ao que el mesmo delimitara nos anos vinte como unha Estimativa estética; pois, en definitiva, do que se vai falar é de valores. Nun primeiro momento aludirá o tratadista ao coñecemento: a traxedia viría ser así o acto de toma de conciencia dos límites do ser humano perante os poderes da necesidade. Sen embargo, ese é tan só un primeiro estadio da súa definición discursiva, compartido coa poesía épica. $\mathrm{O}$ específico da traxedia respecto da épica vénlle dado pola súa natureza de celebración ${ }^{7}$. E aquilo que celebra a traxedia é a virtude do heroe.

A comedia, en troques, ao través da mediación efectual da risa, xulga algo que importaba tamén á traxedia, o determinismo, pero agora por circunscripción ao carácter, mostra Dieste. «Lo cómico es poder hacer previsiones sobre el carácter, aun cuando las circunstancias sean imprevis$\operatorname{tas}^{8}$ (p. 5). A plasmación clásica do cómico reconverte mediante ese expediente ao axente en paciente, pois o mundo circundante devólvelle os seus propios erros, de maneira que as cousas chegan a alzarse en xuíces con capacidade para o restablecemento dun equilibrio, correlativamente secundado na recepción do público por estalido da risa. Resumindo o ata aquí alcanzado cifra o ensaísta:

«El valor de la tragedia se busca en su alusión a los fundamentos del hombre y del mundo.

El valor de la comedia en su alusión a un fundamento verdadero mediante el fracaso de un simulacro, de un fundamento falso.

Lo primero envuelve cierto alcance religioso. Lo segundo cierto alcance moral». (p. 6).

\footnotetext{
${ }^{7}$ En datas próximas a aquelas nas que Dieste escribe o seu tratado reflexionaba Emil Staiger sobre outra diversificación importante do épico e o tráxico. Para o pensador alemán aquela esfera é allea a unha comprensión totalizadora do mundo: «Al épico le falta la consecuencia. Su mundo no es algo sólido. Por eso no lo puede quebrar. Su condición olvidadiza le protege de todo conocimiento, el cual hubiera sido mortal. Si algo se derrumba, la caída no lleva consigo la ruina total del edificio. Pues las partes son autónomas. Contempla sorprendido lo fatal, pero no se anonada, sino que al punto dirige su mirada a lo nuevo, a lo próximo» (Conceptos fundamentales de Poética, Madrid, Rialp, 1966, p. 192; orixinal alemán de 1946).

${ }^{8}$ Lémbrese que xunto coa insociabilidade do personaxe e a insensibilidade do espectador, para Henri Bergson existía unha terceira condición para a irrupción da risa na representación cómica. Exactamente o automatismo, pois «sólo es esencialmente risible lo que se realiza de un modo automático» (La risa. Ensayo sobre la signifi-
} 
A continuación desenvolve Dieste a posibilidade de superación dese esquema clásico a fin de abrir unha idade nova do drama. $\mathrm{O}$ reto, desde logo, non o satisfai a traxicomedia, modalidade que é interpretada como froito dunha indefinición que pretende a penas gardar fidelidade á diversidade da propia vida. Do que se trataría é de encontrar unha esfera íntegra que comprendese, non por mestizaxe nin zigzagueo senón descubrindo unha «clara realidad estética» nova, a comedia e a traxedia. E esa comparecencia do cómico e o tráxico, para ser efectiva, habería de lograrse sen caer en mutua irreverencia de ambos pólos.

A partir deste momento o ensaio toma unha vertente case íntima, de autoindagación. Diríase que Dieste se propuxese alcanzar unha resposta para o seu silencio como dramaturgo, unha resposta que fose punto de apoio para tomar referencias dun regreso ao drama, en fin, da súa recuperación para o teatro. Non semella que conciba outra posibilidade que a de crear o que denomina dramas aleccionadores, aqueles que moverían a unha acción xusta ou previsora, nacidos dun exercicio previo de responsabilidade etopoética. Pero esíxese a si mesmo -e sería xusto recoñecer que algo moi próximo se deixa sentir na súa praxe dramática toda- que a exemplaridade fose verdadeiramente profunda, isto é, que lograse transcender o seu sentido radialmente ao diverso, porque «En poesía los universales deben ser entendidos como centros de intuición concreta a partir de los cuales, por vías de invención poética, se puede llegar a todos los extremos -en la esfera de lo análogo, de lo distinto y hasta de lo opuesto» (p. 8).

É tamén doadamente rastrexábel na producción teatral anterior do autor outro designio que aquí se fixa de modo explícito, o de renunciar simplemente a conmover, ou aínda o de procurar a malsá complicidade do público para solaz dunha crueldade estéril dirixida - ¿como na farsa?a se rir duns personaxes que previamente se conformaron como ridículos a fin da promoción dunha máis sinxela e trivial saña.

cación de lo cómico, Madrid, Espasa-Calpe, 1973, p. 121; orixinal francés de 1900). Pola súa parte, Emil Staiger, no libro que se acaba de citar, subliñou, discutíndoo en ambos casos, que a risa supuña para Kant o carácter de quebra dunha expectativa correspondente a un a priori do mundo, que finalmente se resolve en nada; e, para Vischer, a reconducción dunha expectación da orde oculta do sublime ao da patencia do fenoménico, que se revelaría cun pulo en maior ou menor medida patético (p. 199). 
Coa referencia aos personaxes acádase outro capítulo do texto que engarza co problema da inventio dramática e coa dramaturxia constructora dun mundo. ¿Onde localizar o conflicto? ¿En ficcións non suxeitas a veracidade histórica? ¿Na lenda? ¿Na historia? A clave para achar unha resposta satisfactoria só pode determinarse previo cuestionamento da relación do autor cos seus personaxes, asunto -recórdese- xa presente no «Tratado mínimo». O primeiro parámetro daríao a necesidade. A dos personaxes non pode construírse maquinalmente, pois o seu carácter non é da mesma natureza que as leis físicas que fan funcionar as máquinas. A súa universalidade expresa a liberdade, ou cando menos a impronta dun imperativo moral. Tal e como comenta Peter Szondi lendo a Schelling 9 , o proceso tráxico en canto fenómeno dialéctico queda definido como restitución da indiferenciación do conflicto, pois en Dieste chegan a identificárense necesidade e liberdade (ou, noutra orde conceptual, fracaso e victoria: «el vencedor es a la vez el vencido»). $\mathrm{O}$ asunto dramático, pois, podería surxir por azar, pero sempre porque diante del houbo unha disposición temática previa da fantasía do autor: «la creación del drama empieza antes de escribirlo y aun de planearlo» (p. 14). Xa que logo, para o tratadista o tema é sempre anterior á ocorrencia, permanecendo en ocasións ancorado en espera dunha «ráfaga propicia» (p. 17). Desta maneira a responsabilidade inicial do autor é a de crear un espacio, despexalo, para que o drama poida verse, para expresión dos personaxes que son sempre conciencias, testemuñas. Como se comproba, estamos fronte a unha nova reformulación dunha das máis coñecidas sínteses do pensamento de Schelling, a que ten como pólos a creación inconsciente e a reflexión suxeita a método, a precisión e cálculo.

A parte final destas «Notas» precipita un esquema sobre as relacións múltiples do personaxe, xa sen cinguirse en exclusiva á súa presencia perante o autor ou perante si propio, reinterpretando en fin a súa individuación, que se abrirá nun sentido concordante co pulo dionisíaco en Nietzsche. Indica aquí o tratadista que, ademais de manifestarse fronte a cada un dos outros individuos que o acompañan como dramatis personae, o personaxe faino perante o seu conxunto, entendido como «ámbito

${ }^{9}$ Peter Szondi, Teoría del drama moderno. Tentativa sobre lo trágico, Barcelona, Destino, 1994, p. 183 (orixinal alemán de 1978).

"CUADERNOS DE ESTUDIOS GALLEGOS", Tomo XLVI, Fascículo 111, Santiago 1999. 
moral». Tamén perante a comunidade que representa o mito do colectivo, e mais perante a comunidade esencial que define o espírito (aquí a presencia de Hegel faise nítida). E, finalmente, perante o público e o misterio. Son oito presencias simultáneas que se multiplican polo número total de personaxes. A peculiaridade maior da oratoria teatral consiste en que cada un deles fala simultaneamente para todos os ángulos descritos. Naturalmente, a disposición de tal rede é competencia autorial, e pode verse tamén como despregue dun espacio espectacular que acolle ao espírito, ao público, ao coro e ao personaxe. É o ámbito no que a conciencia humana asiste aos espellos enfrontados daqueles que se definiron como testemuñas recíprocas.

Pasaremos, por último, ao estudio de «El teatro en el Arte y el arte del teatro». Como no caso anterior, trátase dun ensaio inédito, nesta ocasión máis elaborado ${ }^{10}$ e con seguridade tamén máis orixinal. Unha primeira parte, que se acaba proxectando ao tratado na súa totalidade, dedícase ao establecemento dos paralelismos e diverxencias existentes entre a pintura, e en menor medida a música, e o teatro. As tres formas artísticas compartirían o feito de seren unha traducción de ordes de causalidade -do mundo, ao través da conciencia, á representación material- plasmada co mesmo rigor e harmonía que son propios do universo. Pintura e música, non obstante, actúan cunha única materia sobre a que exercen abstracción. No primeiro caso dando lugar a unha presencia corpórea e espacial (pero non a un corpo), que, aínda contando coa abstracción plástica, non deixará nunca de nomear ou, diriamos nós, de representar iconicamente; no segundo, o da música, orixinando unha abstracción temporal xa intanxíbel como materia musical, que non se limita a ser unha masa de sonoridades físicas (como a madeira ou o mármore non se fan materia artística mentres non se evidencian os seus valores escultóricos mediante a abstracción plástica exercida polo escultor). É así que hai un paso ineludíbel entre a materia física e a materia da arte, nun primeiro momento localizado só no designio do artista.

Contrariamente, non existe unha materia que se poida cualificar de teatral, razón pola que, a xuízo do tratadista, «el arte de la escena se ha

\footnotetext{
${ }^{10} \mathrm{~A}$ copia manexada suma un total de trinta e tres folios numerados de xeito correlativo. Á vista dalgunhas marcas incorporadas ao texto pódese supoñer que Dieste non decidira a ordenación definitiva do tratado.
}

"CUADERNOS DE ESTUDIOS GALLEGOS", Tomo XLVI, Fascículo 111, Santiago 1999. 
refugiado en la noción de armonía, dando a esta palabra un sentido peculiar, singularmente impuro, inquietante para el alma que busca potencia en sencillez» (p. 2). Non é esta unha interpretación que convenza a Dieste, que rexeita calquera descrición do teatral como combinatoria orquestrada de signos ou efectos de procedencia múltiple, culminada a posteriori nunha especie de mestizaxe semiótica resultante. «Tenemos que negar que el arte de la escena sea combinación y concierto de las demás artes» (p. 2), advirte, diríase que contra una mala interpretación de Wagner e da súa obra de arte total ${ }^{11}$; pero tamén se pregunta inmediatamente cómo pode o teatro unificar nun só efecto diversas abstraccións físicas que han de corporizarse. Tras recoñecer a existencia de modos intermedios entre a pintura e a arte escénica, particularmente na que apela como escena inmóbil que dá lugar ao cadro tridimensional do retábulo (o cal chegou a moverse na Tebas exipcia), Dieste encontra unha diferencia fundamental entre as artes plásticas, sumada a arquitectura, e o teatro. Mentres que naquelas o espírito actúa previo coñecemento e asunción das respectivas leis das súas materias, no teatro impón a súa lei o espírito, que arela facerse presencia corpórea, que quere articularse en verbo visíbel, de xeito tal que «si la luz y el cuerpo y el sonido y todas las potencias físicas del hombre y de su ingenio se maravillan y aceptan y devuelven el mensaje, tórnanse presencia activa y significativa y aparece el sencillo milagro del teatro» (p. 6). Así, o designado como liña, cor, movemento, son e voz significativa unificaranse no ritmo dramático, non asimilábel -vólvese a advertir- ao musical ou ao das artes plásticas no seu sentido estructural. De optar por isto último a arte escénica redúcese a espectáculo.

\footnotetext{
${ }^{11}$ Nisto hai coincidencia plena con Edward G. Craig, quen nunca estivo disposto a permitir que $o$ teatro chegase a subordinarse a ningunha suma organizada de todas as outras artes ou, simplemente, a subsumirse nunha unificación imposta sobre a especificidade do feito teatral. As bases teórica e estética das que parten Craig e Dieste en canto Regisseurs gardan un paralelismo innegábel. En relación coa opinión de Craig sobre a Gesamtkunstwerk wagneriana véxanse Denis Bablet, The Theater of Edward Gordon Craig, Londres, Methuen, 1981, pp. 66-75 (orixinal francés de 1962); Edgar Ceballos, «Nota del editor» á súa edición de Edward G. Craig, El arte del teatro, México D.F., Universidad Nacional Autónoma de México e Gaceta, 1987, pp. 14-15; e Ricard Salvat, «Edward Gordon Craig, el visionario», Revista de Occidente, 117 (1972), pp. 345 e 359.
}

"CUADERNOS DE ESTUDIOS GALLEGOS", Tomo XLVI, Fascículo 111, Santiago 1999. 
Unicamente se iluminan para Dieste os valores teatrais do ritmo cando se polarizan «hacia el acto de conocimiento dramático del mito los varios impulsos conjugados» (p. 7). Nese momento lógrase a exaltación poética do harmónico, a cal se se quere resaltar por acompañamento multiplicador da música acaba dando na ópera (que, recoñece o tratadista, sempre supón desvanecemento certo de «algo esencial al drama»). Pero antes, sen música,

«...la escena será, en quietud, retablo; en acción, danza descriptiva y, con sus voces, síntesis de danza y elocuencia en que ésta no hace las veces de una música, sino que está ella misma subordinada al tema rítmico general... La acción dramática ha brindado ese tema, que se tradujo en espectáculo como pudiera haberse traducido en música». (p. 7).

Ópera e teatro diferéncianse no mesmo que música e poesía. O drama, por ser poesía, é memoria. E por isto mesmo diríxese ao mito:

«Son, pues, nombres o cifras de recuerdo lo que el teatro en su aspecto sensible representa. No el ritmo de la acción, sino su verbo. Es la memoria poética, nominal y verbal, no el impulso rítmico que nos lleva a participar en una danza, lo que el teatro representa». (p. 9).

Alcanzadas estas conclusións o tratado oriéntase xa a unha serie de capítulos relativamente independentes, sendo o primeiro deles o encabezado polo rótulo «Genio y figura en las leyes del Arte» (pp. 10-16). Regresa este a un dos temas recorrentes na estética diesteana, a delimitación da noción de estilo á luz tanto da teoría da arte como da teoría literaria e aínda da retórica, tantas veces -interpreta o autor-dirixidas indebidamente a unha deturpación do concepto por completo allea á arte. O estilo non é equiparábel, pois, á «expresión de la constancia específica del tipo respecto a la infinita variedad de ejemplos singulares», nin tampouco á pálida pretenciosidade dos mínimos desvíos que aspiran a engrandecer, a maior gloria da beleza, o canon (formal, elocutivo...) no que se contemplan: «Basta querer adentrarse en el alma de tales tipos para descubrir la joroba que ocultan de pedantería» (p. 10). E aquí retomará o escritor, sen variantes dignas de mención, unha definición do estilo que manexaba xa nas súas colaboracións xornalísticas na prensa viguesa nos anos vinte. 
Agora concreta que «el estilo es la clave de trasposiciones que usa el artista para expresar el orden universal en el particular de su oficio» (p. 11), sendo un dos seus primeiros principios, como é lóxico, a abstracción plástica que localiza equivalencias con lealdade á materia que se quere representar.

Ábrese neste punto unha distancia con respecto á definición kantiana da beleza, pois cre o autor que interpretala como forma da finalidade sen a consideración do fin vén plasmar, reductivamente, o imperativo estético emanado da arquitectura ou das modulacións plásticas que incorporan o seu influxo. Que a pintura opte por unha asociación de índole arquitectónica non é reprobábel de seu, pois pode empregar o ritmo para re-presentar conservando a súa unidade nominal -como no Greco-, pero tamén pode dar nunha mera indagación autotélica do ritmo -exemplificada en Rafaelcuxo resultado será sempre ambiguo pola subsidiariedade a que se conduce a obxecto e mito; en suma, pola irrelevancia do seu nomear. Dieste afirma en base a isto que as artes plásticas que renuncian a presentaren os seus froitos como unidades ofrecidas ao coñecemento caen en simple decorativismo.

O fin da composición rítmica na pintura localízase xusto en lograr aquela presentación, o que evitará de paso a desviación mencionada. Outra cosa é -e o simbolismo da obra de Miguel Anxo viría a confirmalo, sempre na estimación do noso autor-que sobre a reciprocidade da mímese operativa nas diversas artes se logre facer «presente en una imagen la resonancia emocional de otra», revelándose ao través desa formulación o misterio dunha comuñón gravitatoria que faculta por si mesma a percepción dunha afinidade. Buonarroti logra encerrar nun corpo de muller «la gravitación de la noche y en ella como en ésta reposan entonces infinitos designios, voluntad dormida, dulce y poderoso fundamento del alba, de todo lo que nace, hijos, victorias, pensamientos lúcidos, y también desastres» (p. 13). A propia estética wagneriana partiría dun pulo semellante, no que o sentimento rítmico da acción se identifica coa materia musical, de modo que o resto das artes confluentes na ópera puideran considerarse como determinacións daquela. E así chegou a aceptalo o propio Nietzsche, imbuído aínda da doutrina de Schopenhauer e Wagner, en Die Geburt der Tragödie (1871), cando identifica a música coa embriaguez dionisíaca e a vontade. Sen embargo, insiste Dieste, a acción dramática que se expresa como música-compracéndose no que é a súa lexítima lei rítmica orixinal-deixa de 
ser dramática: «Así la ópera sólo es posible si se logra restar toda gravedad dramática al mito. Sólo como decoración narrativa (aunque conserve su valor de apólogo elemental) puede compenetrarse con la música» (p. 15). E, de feito, a traxedia só se logra pola gravitación do ser cara ao seu destino, que se sabe, desde o inicio, intransferíbel, polo que non cabe nunca disolver aquela marcha en simple acción nin tampouco en melodía.

O capítulo «Forma y Presencia Activa» (pp. 17-19) volve a partir do ámbito da pintura para posteriormente concluír no do teatro. Protesta Dieste contra a asunción acrítica, tan estendida, de que a pintura italiana, case sempre polarizada pola composición e a consecución do equilibrio, represente a culminación da arte. No seu criterio, mesmo os bos cadros italianos deixan excesivamente fóra ao contemplador, invitado a penas a observar o mundo sensíbel feito quietude. Esa forma tan persuasiva da beleza impide ás veces a captación doutras opcións, como as que poden representar sobre todo a pintura flamenga e a española. Un cadro de Velázquez, por exemplo, non tende a organizarse como sistema «que nos dejase fuera de su campo gravitatorio», e a súa exemplaridade, lonxe de ser ideal, é «activa, real, aunque no fuese realista por la calidad y tratamiento del asunto» (p. 18). Pois ben, ese modo de obxectivación é semellante ao do teatro, que tampouco se contenta coa harmonía interna e a orde formalista. O prodixio da pintura velazqueña é que non sendo efectista sabemos que nos olla, de modo que finalmente se produce unha unión do seu espacio co real, con aquel desde o cal miramos. Así se alcanza unha transfiguración mutua, extática, do real coa súa forma, que no instante mesmo de producirse advirte sobre o artificio e volve a distanciarnos sen deixar de tensar o vínculo atopado con aquela presencia activa (nunca ideal quietude). $\mathrm{Na}$ arte do teatro existe así mesmo unha estética da presencia activa, conclúe o tratadista, nunca ata entón posta «en plena luz teórica», unha estética á que non bastan logros como os da unidade de forma, que quere alcanzar unha unidade de amor semellante á plasmada pola man sabia de Velázquez.

«Poesía Testimonial en la invención dramática» (pp. 20-25) recupera parte do perfilado nos dous tratados anteriores, nalgún caso-como no seu primeiro parágrafo, que reproduce o comezo do capítulo segundo do «Tratado mínimo»- de maneira textual. A poesía dramática non conta unha historia; en realidade convoca ao público para facelo testemuña, «y más 
que personalmente, civilmente» ${ }^{12}$ (p. 20). Algo non totalmente disímil logra a poesía épica, pero no seu caso só por mediación dun narrador Dieste di un poeta-que se transmuda en testemuña presencial e que aspira a trasladar ao auditorio tal convicción. A épica de carácter novelesco afastaría xa algo máis, porque nela o narrador oriéntase a facer gala da súa infinita potencia testemuñal. A novela, finalmente, substituíu a forza do testemuño directo por leis que o son da interpretación e a sensibilidade; o que fai esta modalidade narrativa segundo Dieste é interpretar e evocar.

Por tanto, a forma de obxectivación do teatro só se atopa, ata fraternizaren, na poesía épica. Nalgún caso, como en Esquilo («pero muy rara vez después»), deica o extremo de rozarse a omnipresencia do narrador épico feita voz no relato do rapsodo. Rexistra o tratadista confluencia tamén no que Aristóteles apelaba como os obxectos, pois os protagonistas son en ambos casos os homes de corazón xigantesco. Iso foi así no principio, que pertence á traxedia e aos heroes. Pero axiña os espectadores quixeron vérense a si mesmos no teatro, de modo que puideron converterse en testemuñas civís da'súa propia circunstancia.

O carácter testemuñal da presencia do espectador en asemblea impón a unidade de tempo, explica Dieste. A evocación como recuperación de datos informativos do pasado, tan tipicamente novelesca, era xa necesaria ao teatro grego, pero este resolveu o problema outorgando a eses antecedentes efectivo peso dramático. Dese modo o remoto dialogaba co actual e non se limitaba a actuar causalmente. Os medios atopados foron plurais:

«La solución más pura cuando masas episódicas muy lejanas se influyen poderosamente y reclaman presencia con igual imperio, fue tratarlas como piezas escultóricas que cumplen, separadas, todas las exigencias de la unidad de tiempo, y en sucesión -o unidas luego en el recuerdo como figuras de un retablo- componen la unidad del mito. Tal es la razón de la trilogía antigua y de otras unidades múltiples que pueda concebir el ingenio dramático». (p. 23).

${ }^{12}$ De aí a necesidade do coro, apuntarase posteriormente, pois o coro quere representar «la unanimidad del testimonio tradicional», que pertence ao inmemorial e é por iso mesmo liturxia (p. 22).

"CUADERNOS DE ESTUDIOS GALLEGOS", Tomo XLVI, Fascículo 111, Santiago 1999. 
Mediante razoamentos como este que presento proporá o teórico que os valores dramáticos naceron en Grecia das propias necesidades da composición espectacular. Pero o mesmo, e non menos, sucedeu á ínversa; ata o punto de afirmarse que o xeito de obxectivación teatral implica unha teoría do coñecemento. E non só activa senón tamén pasiva. De sorte que se se sobreexcitan os pulos do público por contaxio desde o escenario, estarase ás portas da decadencia. Dieste lembra que xa Eurípides soubo intuílo. O fenómeno contrario presupón incluso menos riscos, como demostra o personaxe de Hamlet na traxedia de Shakespeare, a quen «la acción le está vedada por la razón vacilante», de forma que o seu to be or not to be ten sentido estrictamente dramático, para subliñar a falta de testemuño dos outros, só resolta con frenesí imparábel na culminación da obra.

Finalmente, «Virtud del mundo y del hombre» (pp. 26-33) determina a necesidade de que todo o que concorre á escena se faga verbo teatral. Dieste lamenta aquí a falta de instrumentos precisos de análise para delimitar debidamente aquela necesidade. Desconfía absolutamente da retórica e, en menor medida, da poética e do que chama «esteticismo académico». Mostra maior confianza na filoloxía, en especial nunha nova filoloxía que ampliase o seu ámbito de estudio ás artes non literarias e que sen dúbida habería de refundarse como disciplina comparatista. Faltando o seu método, e consecuente cos rumbos seguidos ata aquí, o tratadista resolve fiar na linguaxe metafórica, na análise dun tropo -especificamente do seu vehículo-que interpreta que serve ao seu programa investigador, sobre todo porque se asegura da súa propia transparencia, da súa pureza en relación con analoxías secundarias e da súa fraternidade co campo comparado, ao que se proxectarán ulteriormente as conclusións reveladas.

É este vehículo de novo o da pintura, en concreto a manierista do Greco na súa evolución da etapa veneciana á española. Dieste precisa que nesa adaptación o pintor non deixou de entender o cadro como unha perfecta ecuación plástica, pero a medida que se adaptaba a unha nova sensibilidade comunal -e iso se mostraría ben na serie sobre o tema de Xesús expulsando aos mercaderes do templo- os resultados prescindían de accidentes e gañaban en presencia dramática, de modo que o derradeiro cadro da serie, non deixando de ser pintura, faise xa teatro inmóbil, que cristaliza «en el instante más luminoso de su acción». Se Rubens ou Tintoretto conseguen que o observador participe na acción (o veneciano incorporando mesmo 
unha vía ao ascetismo que substantiviza compoñentes soltando progresivamente tamén o lastre do accidental), O Greco extrema o logro levando o acto de coñecemento ao seu límite, facéndonos «participar con todo el ser en el éxtasis despierto de la adoración» (p. 29). A súa pintura é, pois, unha exaltación dun acto de coñecemento propiamente dramático, consistente para Dieste na revelación -téñase en conta o ren-demento deste concepto na crítica de arte diesteana e, en xeral, en todo o seu edificio estético-en acto presencial de «la hondura poética del ser en un instante». Isto fai que se transcenda o cadro ou a anécdota, algo que para o gusto artístico do tratadista só conseguiron os mellores de entre os pintores das escolas holandesa e española, e moi particularmente O Greco:

«Su dicción llega a alcanzar la máxima desnudez, pero es tan sabia en su pureza que parece esconderse -y no se esconde...- cuando la astucia del ingenio quiere descifrarla». (p. 29).

Pero a organización dos seus cadros non é só musical ou compositiva. Cada un dos seus elementos, alén da beleza e o equilibrio ópticos, semellan saber cal sexa o sentido íntegro do cadro -que ao seu xeito testemuñanademais do seu propio e o do resto de compoñentes, aos que non ignora xamais. Desta maneira, cores, formas, pulos de diversa orde... poden chegar a polarizarse coordinadamente co mesmo acto de coñecemento que a totalidade do achado plástico supón, e nese sentido, alcanzan a participar no propio acto cognoscente ${ }^{13}$.

E no marco que se deseña, ut pictura, theatrum ${ }^{14}$. Dieste recupera neste punto, co propósito que se manifestou, un segmento do «Tratado mínimo» que xa vimos, aquel no que se esixe que todo aquilo que aparece en escena -mesmo unha rocha- ten que asistir ao acto dramático, de maneira que se non o fai debe ser eliminado. E insiste novamente en que

\footnotetext{
${ }^{13}$ Xusto de aquí derivaría ademais a supresión do accidental, que en definitiva vén sendo todo aquilo que non asiste ao acto cognoscitivo.

${ }^{14}$ Valórese a esta luz o apuntado sobre o carácter pictórico do teatro diesteano, sinalado entre outros estudiosos por Ricard Salvat, «La obra de Rafael Dieste», Diario de Barcelona, 28 de xullo de 1974 (pode verse en Documentos A, 1 (1991), pp. 159-160), e Francisco Pillado Mayor «A fiestra valdeira en el teatro gallego», Documentos A, 1 (1991), p. 126.
}

"CUADERNOS DE ESTUDIOS GALLEGOS", Tomo XLVI, Fascículo 111, Santiago 1999. 
nin o concerto nin a síntese das formas rítmicas de cada unha das esferas sensibeis intervintes (óptica, acústica e cinética), orientados ou non á sublimación musical do ritmo, ou aínda á danza, poden constituírse en camiño lexítimo para a representación escénica. Se isto é xa reprobábel na pintura -aínda que como trampa obtivese a súa cota de éxito ao longo dos diversos estilos e períodos históricos- moito máis no teatro.

O Greco conseguía nos seus cadros chegar ao límite xusto da palabra e o mito. Por iso, para velos na súa profundidade plena, faise precisa a linguaxe e a memoria, complementa o noso autor. $E$ isto a pesar de que a pintura se lle queda detida ou suspensa «en el silencio poético del éxtasis», por tanto, como non podería ser doutro xeito, sen ter convertido os valores plásticos en valores dramáticos -os cales no tratado, como se pode comprobar, teñen sempre unha dobre vertente, semántica e pragmática-, tan só dirixidos na boa dirección para inducir, no observador unha contemplación dramática.

Pois ben, para Dieste os perigos de facerse música ou facerse danza, que con decisión debe esquivar a pintura -e que soubo solventar en canto problema a do Greco-, embóscanse tamén para adulterar o teatro, ou para intentar a súa seducción. A única posibilidade de reacción, o éxito na salvación do teatro, estriba segundo as razóns do tratado diesteano en outorgar iniciativa ao signo dito e á memoria, que se fan presentes por mediación do mito. A palabra e a acción dramáticas son absolutamente irrenunciabeis, concepción esta que sen deixar resquicio á dúbida confirmara xa a creación toda de Dieste como poeta dramático e, antes incluso, a súa producción crítica desde as primeiras entregas, as publicadas no xornal vigués El Pueblo Gallego a partir de 1925. 